\title{
THE ENGAGEMENT OF EMPLOYEES IN THE \\ STRATEGy Process ANd FIRM PERFORMANCE: \\ THE ROLE OF STRATEGIC GOALS AND ENVIRONMENT
}

\author{
Linda F. Tegarden \\ Virginia Tech \\ Blacksburg, VA \\ Yolanda Sarason \\ Colorado State University \\ Fort Collins, CO \\ J. Stephen Childers \\ Radford University \\ Radford, VA \\ Donald E. Hatfield \\ Virginia Tech \\ Blacksburg, VA
}

\begin{abstract}
Despite the call to engage employees in strategy making processes, empirical evidence that ties this engagement to financial performance has not been forthcoming. This study fills this gap by investigating whether involving employees in the strategy making process leads to a higher achievement of strategic goals and subsequently increased financial performance. Our findings suggest that the link between strategy making processes and financial performance may be underestimated unless strategic goals are included as a mediator. We also find environmental dynamism moderates the relationships we investigate. Under conditions of low dynamism, there is a stronger relationship between the engagement of employees and strategic goals related to innovation than under conditions of high dynamism. Conversely, strategic goals related to quality have a stronger relationship with engagement of employees under conditions of high dynamism when compared to conditions of low dynamism.
\end{abstract}

The importance of involving employees throughout an organization in the strategy making process has been recognized by traditional academic researchers (e.g. Burgelman, 1991; Floyd \& Wooldridge, 2000; Hart, 1992), as well as consultants and practitioners (e.g. Hamel \& Prahalad, 1994; Kaplan \& Norton, 1996). One rationale behind the use of multi-level strategy processes is to provide employees with a better understanding of the company's strategy and build a 
stronger commitment to achieving the goals in the implementation of the strategy (Floyd \& Wooldridge, 2000; Hamel \& Prahalad, 1994; Kaplan \& Norton, 1996). A company's strategy can also be facilitated by employee involvement because knowledge and information relevant to strategy making is dispersed throughout the organization (Miller \& Monge, 1986). Cognitive model theorists (Anthony, 1978; Frost, Wakely \& Ruh, 1974) propose that when employees have more complete knowledge about their jobs and operations they can provide better information. Involvement in strategy making also allows employees to know more about implementation of decisions. For example, ideas that support new innovations often come from those employees that are in direct contact with the customer (Von Hippel, 1988). In order for innovation to be a source of competitive advantage for a company, there must be organizational processes that allow these ideas to be brought forward and integrated into the activities of the company (Burgelman, 1983).

Despite the call for more investigations into the relationship between strategy making process and firm performance (Chakravarthy \& Doz, 1992; Huff \& Reger, 1987), there has been relatively little empirical research on this link, especially when strategy making processes involve multiple levels of the organization (Floyd \& Wooldridge, 2000; Rajagopalan, Rasheed, \& Datta, 1993). While the intensity and use of employee involvement practices is on the increase, the strategic impact of such practices has not been adequately investigated. This may be because most studies focus on narrow definitions of employee involvement (Ledford \& Lawler, 1994). Our study uses a broad definition of employee involvement in strategy process to include information sharing, decision making, experimentation, understanding of company goals, and iterative strategy making that involves multiple levels of the organization. A broad definition captures the variety of involvement ranging from information sharing to actual decision making. We suggest that aspects of such involvement should relate to achievement of strategic goals.

The two types of strategic goals tested in this study are quality and innovation. It is suggested that both require employee involvement and empowerment to make decisions (Lawler, Mohrman, \& Ledford, 1995; Burgelman, 1991). In addition, these goals often create a tension between striving to have organizational processes that ensure consistent quality and organizational processes that facilitate creativity and innovation (Brown \& Eisenhardt, 1998; Jelinek \& Schoonhoven, 1990; Miron, Erez, \& Naveh, 2004). We also propose that multi-level strategy processes support the achievement of quality more than the achievement of innovation, since achievement of these goals require different levels of cooperation and competition among employees within an organization. These differences in the strength of the path relationships for quality and innovation are proposed to vary with levels of environmental dynamism (Miller \& Friesen, 1983).

This study contributes to the understanding of the relationship between strategy processes and financial performance by examining information and communication benefits derived from use of multi-level strategy processes. We 
extend this work with insights from cognitive and communication models that focus on information and communication benefits associated with participative management (Miller \& Monge, 1986; Monge, Cozzens, \& Contractor, 1992). We postulate that the relationship between multi-level strategy processes and firm financial performance is not a direct link. Rather, we suggest that involving multiple levels of the organization in strategy processes enables higher commitment and achievement of strategic goals because the quality of information used in decisions and communication of what strategies and goals are important increases with organization-wide participation in strategy processes. Moreover, it is the successful achievement of these strategic goals that leads to superior financial performance. Thus, we propose that strategic goals are an essential mediating variable in understanding the multi-level strategy process - financial performance link. Figure 1 outlines the model we propose and test.

\section{Figure 1}

\section{The Link Between Multi-Level Strategy Processes, Strategic Goals and Firm Performance and Moderating Role of Environment}

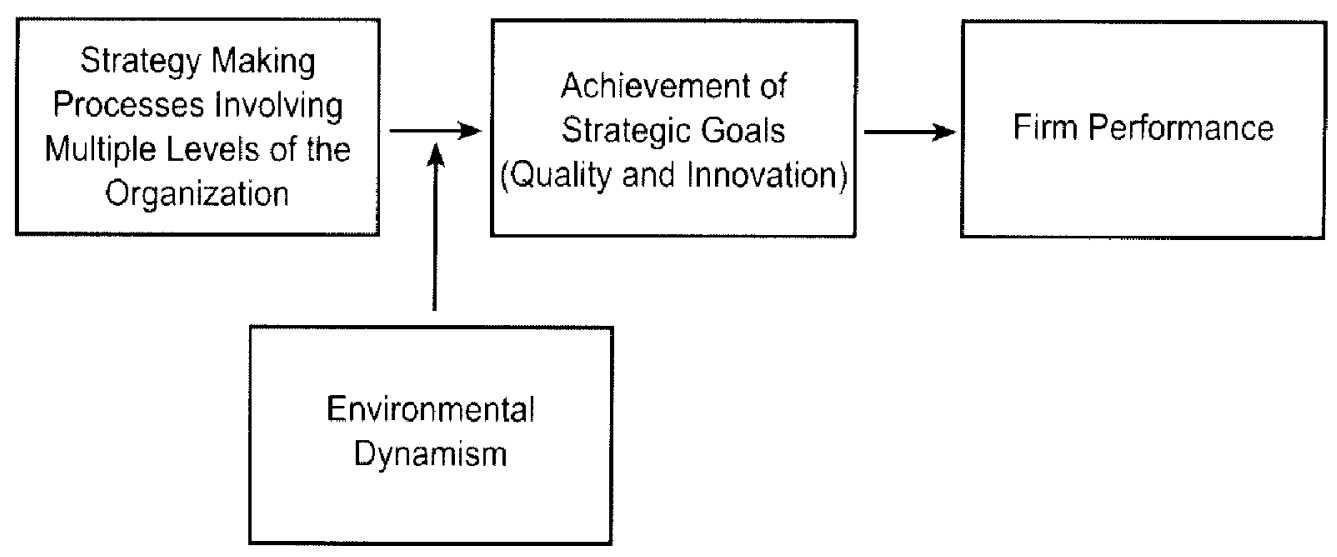

We begin with a discussion of the rationale leading to our hypotheses. Subsequently, we describe the nature of our methodology and results. We end with a discussion of our conclusions and implications for research and managers.

\section{Literature Review and Hypotheses}

Strategy process research is concerned with how a firm's administrative systems and decision processes influence its strategic positions (Chakravarthy \& Doz, 1992). There has been a call for more investigations of the links between firm performance and strategy processes in order that our understanding be more complete (Floyd \& Wooldridge, 2000; Huff \& Reger, 1987). For the link between strategy process and firm performance to be made, there is a need to explicate the relevant mediating and moderating variables (Rajagopalan et al., 1993). We are 
proposing that strategic goals are important, yet overlooked, mediating variables in the strategy process - financial performance relationship. We will begin with a discussion of the extant work on strategy processes and firm performance.

There is emerging empirical work that illustrates the potential competitive advantage from the use of multi-level strategy making. For example, Wooldridge and Floyd (1990) find that greater participation and involvement by middle level managers in strategy formation results in greater commitment and understanding of strategy, as well as improved economic performance. Monge et al. (1992) finds that communication variables, like access to information throughout the organization, increase the number of innovations in a firm. Powell (1992) shows that strategic planning processes, that are not available on the strategic factor market, can be sources of competitive advantage. Miller and Lee (2001) give evidence that collaboration among employees toward decisions results in improved firm performance. Tegarden, Sarason, and Banbury (2003) give evidence that processes drawing upon all employees are more likely to have a greater influence on strategic performance rather than financial performance. Finally, the use of participative management practices has been on the rise in organizations because most report success, especially with self-management teams (Lawler, Mohrman, \& Ledford, 1992) and for more complex tasks (Ledford \& Lawler, 1994).

While these studies have begun to open the organizational black box and provide growing evidence that use of multi-level strategy processes can help explain firm performance, there is still a gap in our understanding of how and why involving employees in the strategy making processes improves performance. We offer that involving employees in strategy making results in higher achievement of strategic goals because of higher commitment to such goals and it is this achievement of strategic goals that leads to higher financial performance. In order to support this argument, we draw from participation and empowerment literatures to establish the mediating role of strategic goals with multi-level strategy processes and firm performance.

There is a plethora of literature that focuses on the outcome effects of employee involvement in organizations. Multi-level strategy processes encompass the notions that involvement of employees and managers is beneficial to organization outcomes. Both motivation and communication are central to the idea that employee involvement produces higher satisfaction and productivity. The emphasis is on outcomes that impact strategic position rather than financial performance. Each set of literature is summarized below as to the links between greater involvement of employees and managers and its impact on organizational performance.

Involvement as a subject has a long history, dating back to McGregor's (1960) idea that workers can contribute to governing their own situations. McGregor's specification of Theory $\mathrm{X}$ and Theory $\mathrm{Y}$ focus on beliefs about human nature and how they impact work to be done. Likert (1961) described management models that went beyond the traditional command and control structure. The work of McGregor (1960) and Likert (1961) encouraged investigations on participative management during the 1960s. Participative management "recognized the good- 
will, interest, talent, and needs of employees, and encouraged open communication and cooperation between management and employees" (Forrester, 2000: 67).

During the 1980s, Lawler and his colleagues (Bowen \& Lawler, 1992; Lawler, 1986, 1992; Lawler et al., 1995) extended this idea by identifying levels of involvement from low to high. The low end of involvement is idea generation, suggestions that employees give to managers on ways to improve operations. A higher level of involvement is giving employees the ability to determine the methods they employ on the job. The highest level of involvement is giving lower level managers and employees the ability to influence decisions beyond one's own job that affect the business at large. The major reason for involving employees in decision making is that it will improve organizational effectiveness.

The empowerment literature focuses on empowerment as a motivational construct that affects individual and organizational outcomes (Rudolph \& Peluchette, 1993). Empowerment comprises individual cognitions and perceptions that constitute feelings of behavioral and psychological investment in work (Conger \& Kanungo, 1988; Spreitzer, 1995, 1996; Zimmerman, 1990). These include meaning, self-determination, competence and impact. It describes "people's belief in their capabilities to mobilize the motivation, cognitive resources, and courses of action needed to exercise control over given events" (Ozer \& Bandura, 1990, p. 472). Empowerment also relates to a belief in self-efficacy and an expectation that effort will lead to performance (Koberg, Boss, Senjem, \& Goodman, 1999). "Empowerment implies the freedom and the ability to make decisions and commitments, not just to suggest them or be part of making them" (Forrester, $2000, p .67$ ). It is recognized that organizations are characterized with an increasingly blurred distinction between managers and workers with a growing reliance on horizontal structures and peer networks (Kantor, 1989; Pfeffer, 1994). The importance of empowering employees is also discussed in the entrepreneurship literature (Kuratko, Hornsby, \& Corso, 1996; Willard, Krueger, \& Fesser, 1992). When the founder shifts from creation to exploitation, employees should be empowered with the ability to create and facilitate adaptation and change. The founder's shift to a more managerial role requires an increase in employees' roles in identifying and adapting to change. As such, empowerment has received increasing attention. Empowerment has been shown to affect managerial and organizational effectiveness (Spreitzer, 1995). Perceptions of empowerment can enhance the value of work for individuals, increase job satisfaction and contribute to work productivity and success (Eylon \& Au, 1996; Fulford \& Enz, 1995; Spreitzer, 1995). For example, Koberg, et al. (1999) found that empowerment perceptions were associated with increased job satisfaction and work productivity/effectiveness. The important point here is that outcomes studied in relationship to empowerment include worker effectiveness/productivity and job satisfaction, not a direct link to financial performance.

Another stream of research is the participation literature which focuses on participation's influence on satisfaction and productivity. The primary foundations of this literature are communication and affective models that predict the positive 
relationship between participation and organizational outcomes, like innovation, productivity and job satisfaction (Miller \& Monge, 1986; Monge et al., 1992; Wagner, 1994). Communication models assume that participation in decision making enhances the flow and use of important information in organizations. Theorists (Anthony, 1978; Frost, et al., 1974) propose that workers typically have more complete knowledge of their work than management; hence if workers participate in decision making, decisions will be made with better pools of information. In addition, it is suggested that if employees participate in decision making, they will know more about implementing work procedures after decisions have been made (Maier, 1963; Melcher, 1976). In essence, the role of information and communication is central to the positive relationship between participation and organizational outcomes. Some support for this assertion is found in Miller \& Monge's (1986) meta-analysis. Stronger support is shown in the Monge, et al. (1992) study of participation and organizational innovation.

In addition to the communication predictors, participation literature also stresses the motivational predictors or affective models of participation, which are the foundations of the human relations school of management (Blake \& Mouton, 1970; Ritchie \& Miles, 1970) as well as the theory supporting empowerment. The relationship between participation and organizational outcomes is indirect. Participation will enhance organization effectiveness through intervening motivational processes: participation fulfills needs, fulfilled needs lead to satisfaction, satisfaction strengthens motivation, and increased motivation improves worker's productivity. A small, but positive relationship is supported by the literature (Cotton, Vollrath, Legnick-Hall, \& Froggatt, 1990; Wagner, 1994), yet most studies focus on trivial changes in complex systems (Ledford \& Lawler, 1994). In any event, again, participation studies focus on its relationship to organizational outcomes and effectiveness and not financial performance.

Engaging employees at multiple levels of the organization in the strategy making process results in greater commitment to strategic goals (Locke, Latham, \& Erez, 1988), as well as the potential for improved decision making, either through use of more relevant information or higher satisfaction, which in turn leads to the greater motivation to achieve goals. While we recognize that commitment to strategic goals and achievement of strategic goals are two different constructs, we follow the logic of Lock, et al. (1988, p. 24) that commitment to goals can be inferred from performance. As they state, "(w)hile performance cannot be a catch-all measure of commitment, since performance can be caused by other factors such as ability, judicious use of inference from performance seems both theoretically and empirically justified." Consistent with this insight, Salancik (1977) indicates that behavior or action is the ultimate proof of commitment and thus, by implication, the most accurate measure of it. Thus, multi-level strategy making processes are directed toward the achievement of organizational goals, such as innovation, efficiency, and quality (what we call strategic goals). Stated more formally: 
Hypothesis la: The use of multi-level strategy processes is positively related to the achievement of strategic goals.

The literature on multi-level strategy process has traditionally focused upon commitment to goals or a strategy rather than financial performance. Conventional strategy models always focus on strategy (a stream of actions) that can lead to superior strategic performance. When multi-level actions are "directed" by a commonly agreed on set of strategic goals, the result is higher financial performance. As such, we propose that:

Hypothesis 1b: The achievement of strategic goals mediate the relationship of multi-level strategy processes and financial performance.

\section{Type of Strategic Goal}

We investigate two types of strategic goals, goals that focus on the achievement of quality and goals that focus on the achievement of innovation. Quality focuses on striving to be more effective and efficient, while innovation focuses on developing new products and services. We propose that the degree of internal cooperation and internal competition required to achieve these strategic goals differs. This difference impacts the effectiveness of multi-level strategy processes on firm performance.

Striving for quality requires organization members to collaborate and coordinate their decisions and actions (Dean \& Bowen, 1994; Powell, 1995). To achieve higher quality, organization members must coordinate their actions across functional and hierarchy boundaries (Floyd \& Wooldridge, 2000). For example, the quality of a product should be tracked throughout the value chain of a firm, from inputs to manufacturing through sales and customer service. Feedback and learning associated with the achievement of higher quality requires that the organization provides cross-functional communication, not only within the organization but also with suppliers and customers (Hart, 1992). Decisions reflect cooperation and tight coordination between related entities to achieve high quality. Employees are empowered at multiple levels to make decisions that impact quality, but they must be orchestrated within a tight, cohesive system. A strong commitment to quality by all employees is necessary to achieve a goal of quality (Bowles, 1992; Gabor, 1990; Port \& Smith, 1995). Multi-level strategy processes include the aspects of learning and adaptation required to achieve greater quality. The relationship between multi-level strategy processes and the processes required to achieve quality are highly complementary in nature, as both require cooperation and coordination in the development of strategy and the implementation of quality.

Greater achievement of the strategic goal of innovation also requires multiple levels of involvement in strategy processes. As others have advocated (Damanpour, 1991, Kantor, 1988), it is important that individuals are encouraged to continually commit to product and process innovation in order for creativity not 
to be strangled. While innovation as a strategic goal requires employees at all levels of the organization to commit to new product development, there is a lesser need for systematic coordination across all levels and functions of the organization to achieve it. In contrast to those firms in pursuit of quality, firms striving for innovation use teams (usually multi-functional) that compete for resources (Burgelman, 1983). Thus, the innovation process is rooted more in competition rather than cooperation. Because the overall coordination required to successfully implement innovation is lower, the effectiveness of multi-level strategy processes on innovation goals will be lower relative to quality goals.

To summarize, high achievement of innovation requires a team-level goal commitment, more than an organizational-level goal commitment. In addition, for innovation, coordination is confined to fewer individuals in the organization and there is competition between teams for resources. In contrast, achievement of quality requires greater coordination across the entire organization. As such, the use of multi-level strategy processes is more effective when the goal requires broader coordination and communication across a greater number of organizational members. In the case of innovation, organization members need only to communicate with the specific team members involved in a specific innovation project. Since multi-level processes facilitate cooperation and commitment, the fit between quality and multi-level processes is higher compared to the fit with innovation and multi-level processes. Therefore, the link between multi-level strategy processes and firm performance will differ. We hypothesize that:

\section{Hypothesis 2: The indirect relationship between multi-level pro- cesses and firm performance is stronger when the strategic goal is quality rather than when the strategic goal is innovation.}

\section{Environmental Dynamism as a Moderator}

In order to test the strength of our predictions and argument, we investigate the role of environmental dynamism on the differences between quality and innovation. Environmental dynamism is defined as both technological change and unpredictable instability (Miller \& Friesen, 1983; Powell, 1996) and has been an important variable in investigations of strategy processes and firm performance (Hart \& Banbury, 1994; Tegarden et al., 2003). While investigations have yielded mixed results (Miller \& Cardinal, 1994; Rajagopalan et al., 1993), there is growing evidence that strategy processes such as strategic planning (Brews \& Hunt, 1999) and rational decision making (Goll $\&$ Rasheed, 1997) are more effective in dynamic environments. We predict that the role of environmental dynamism will depend on whether the strategic goal is quality or if the strategic goal is innovation.

We propose that environmental dynamism will positively impact the multi-level strategy process when the strategic goal is quality. To be successful in dynamic environments, firms must adapt to unpredictable external changes. Firms that strive for high quality have more connections with external actors because quality 
requires extensive collaboration with both suppliers and customers. In addition, organization members are more connected to ensure that coordination and communication transpires. Because of the greater number of linkages implemented in an organization when quality is a priority, information regarding changes in the environment will transmit to a greater number of organization members faster. Thus:

Hypothesis 3a: The strength of the relationship between multilevel strategic processes and the strategic goal of quality is greater when environmental dynamism is high compared to when environmental dynamism is low.

We suggest that the relationship between multi-level strategy processes and the strategic goal of innovation will be negatively impacted by environmental dynamism. In contrast to the implementation mechanisms in place for quality, the number of communication and coordination links among employees is lower with the goal of innovation, resulting in less information being relayed about the changing environment. While a single project team can respond quickly to changes, the entire organization will take longer to absorb and determine the strategic impact of external changes. The use of multi-level strategy processes with processes that support innovation are more likely to generate multiple interpretations of the nature and impact of change because employees are often tied to individual projects with individual goals and reward structures. This is also more likely to result in greater negotiation to reach agreement about the company's future strategy. Moreover, we suggest that under conditions of low dynamism it is even more important for firms to continually innovate to stay ahead of their industry's competitors. Thus we predict effectiveness will decline with the use of multi-level strategy processes with the goal of innovation in more dynamic environments. We hypothesize that:

Hypothesis $3 \mathrm{~b}:$ The strength of the relationship between multilevel strategic processes and the strategic goal of innovation is greater when environmental dynamism is low compared to when environmental dynamism is high.

\section{Method}

Our sample was obtained from the 1996 CorpTech Directory of Technology Companies. This data set of U.S. firms was published by the Corporate Technology Information Services. The range of these technology industries includes advance materials, biotechnology, defense, environmental, manufacturing equipment, transportation, and chemicals. The relationships being tested are not time dependent. Following guidelines for strategy research, there is no reason for suspecting that the age of the data influenced the results in this study (Robins, 2004). 
We randomly selected 2,000 organizations from among the firms provided by the CorpTech Directory and mailed surveys to the chief executives of these firms. Research indicates that top administrators provide reliable information about basic envirommental and organizational characteristics of their organizations (Miller \& Friesen, 1983). A total of 377 surveys were returned for a $19 \%$ response rate. This response rate is not atypical for research using CEOs as respondents (Milliken, 1990). Non-responding firms did not differ significantly from responding firms in the proportion of privately owned firms, number of employees, sales revenue, annual percentage growth in number of employees, or year of formation.

We eliminated returned surveys with incomplete information, leaving the data from 335 surveys for use in our statistical analysis. Most (80\%) are private firms and over half of the firms report annual sales revenues of less than $\$ 2.5$ million and employ fewer than 25 workers. Less than $2 \%$ employ over 2,500 workers and about $3 \%$ have sales of over $\$ 500$ million. Approximately $8 \%$ of the firms in the sample have been in business for 25 or more years, approximately $36 \%$ for between 10 and 24 years, and the remaining firms have been in business for less than 10 years.

Measures. The scales used to construct the variables in this investigation have been standardized and validated by other researchers. The questions were presented on a five-point Likert scale. Variables are measured using averages across multiple items.

Multi-Level Strategy Processes. Multi-Level Strategy Processes is measured using the average of five items developed by Hart and Banbury (1994). These strategy processes reflect engagement of employees at all levels of the organization. Items in this measure include the questions: "Strategy is made on an iterative basis, involving managers, staff and executives in an on-going dialogue." and "Most people in this company have input into the decisions that effect them." The alpha coefficient for this measure is 0.74 .

Strategic Goal-Quality. Quality as a strategic goal is measured using the average of three items developed by Hart and Banbury (1994). This measure included answers to questions focusing on whether the respondents' organization produced high quality of product (service) or if quality was a focus in the technical product/ service design and development. The alpha coefficient for this measure is 0.61 .

Strategic Goal-Innovation. Innovation as a strategic goal is measured using the average of three items developed by Hart and Banbury (1994). This measure included answers to rating the company's performance over the last three years on activities such as the extent of product/service changes over the past five years and the number of new products/services in the next year. The alpha coefficient is 0.66 .

Strategic Goals Combined. The items to measure the strategic goal of quality and the strategic goal of innovation were combined for an overall average of strategic goals. The alpha coefficient for this measure is 0.70 . 
Financial Performance. Financial Performance is measured as an average of a five-item scale developed by Powell (1995). Respondents are asked questions that reflect the extent that revenue, growth, or financial performance has exceeded their competitors' or has been judged outstanding by the respondent in the last three years. Although the measures obtained are subjective, past research has validated the use of such measures for performance (Lawrence \& Lorsch, 1967), and is appropriate for samples such as ours in which most $(80 \%)$ of the firms are privately owned. The alpha coefficient for this measure is 0.91 .

Environmental Dynamism. Environmental Dynamism is measured as an average of five items from a scale developed by Powell (1996) with questions related to the frequency of change in the environment and the predictability of this change (Miller \& Friesen, 1983). Respondents were asked the extent to which they agreed with statements such as "Demand in our industry has been growing rapidly in the past 3 years" and "Our industry is more unstable than most, changing more quickly and unpredictably." The alpha coefficient for this measure is 0.73 .

Typically, alpha coefficients of multi-item measures should fall within a range of 0.70 and 0.90 for narrow constructs, and 0.55 to 0.70 for moderately broad constructs (Van de Ven \& Ferry, 1979). All of the coefficient alphas in this study are in these ranges and are consistent with those used in other studies using these variables (Hart \& Banbury, 1994; Tegarden et al., 2003).

\section{Results}

Table 1 reports the descriptive statistics and correlations for the variables. Results of the correlations show that financial performance is not significantly related to multi-level strategy processes or environmental dynamism. However, multilevel strategy processes is significantly related to the innovation strategic goal, quality strategic goal and the combined strategic goal. As would be expected, strategic goals are related to each other. Interestingly, environmental dynamism is significantly related to each strategic goal, as well as the goals combined.

Hypothesis 1 a states that the use of multi-level strategy processes is positively related to the achievement of strategic goals. To test this relationship we used regressions, with combined quality and innovation, quality alone, and innovation alone as the dependent variables and multi-level strategy processes as the independent variable. Table 2 indicates that multi-level strategic processes are significantly related to the combination of quality and innovation as the strategic goal $(F=88.52, p<0.001)$, quality as the strategic goal $(F=80.06, p<.001)$ and innovation as the strategic goal $(\mathrm{F}=40.64, \mathrm{p}<.001)$. Thus, Hypothesis $1 \mathrm{a}$ is supported. 
Table 1

Means, Standard Deviations and Correlations $(n=335)$

\begin{tabular}{|c|c|c|c|c|c|c|c|c|}
\hline Variables & Mean & $\begin{array}{l}\text { Std. } \\
\text { Dev. }\end{array}$ & 1 & 2 & $\mathbf{3}$ & 4 & 5 & 6 \\
\hline 1. Multi-Level & & & & & & & & \\
\hline $\begin{array}{l}\text { Strategy Processes } \\
\text { 2. Quality Strategic }\end{array}$ & 3.85 & .58 & 1.00 & & & & & \\
\hline $\begin{array}{l}\text { Goal } \\
\text { 3. Innovation }\end{array}$ & 4.08 & .60 & $.44^{* * *}$ & 1.00 & & & & \\
\hline $\begin{array}{l}\text { Strategic Goal } \\
\text { 4. Combined Quality }\end{array}$ & 3.57 & .73 & $.33 * * *$ & $.37^{* * *}$ & 1.00 & & & \\
\hline $\begin{array}{l}\text { \& Innovation } \\
\text { 5. Financial }\end{array}$ & 3.82 & .55 & $.46^{* * *}$ & $.79 * * *$ & $.86 * * *$ & 1.00 & & \\
\hline $\begin{array}{l}\text { Performance } \\
6 \text {. Environmental }\end{array}$ & 3.14 & .96 & .08 & $.19 * * *$ & $.26 * * *$ & $.28 * * *$ & 1.00 & \\
\hline Dynamism & 3.61 & .77 & $.26^{* * *}$ & $.27^{* * *}$ & $.28 * * *$ & $.33 * * *$ & .07 & 1.00 \\
\hline
\end{tabular}

One-tailed test: ${ }^{*} \mathrm{p}<.05,{ }^{* *} \mathrm{p}<.01,{ }^{* * *} \mathrm{p}<.001$

Table 2

Regression Model Estimates to Test Hypotheses 1 a

\begin{tabular}{c|c}
\hline Regression Model For Paths & Estimates \\
\hline Model 1: & \\
DV: Combined Quality \& Innovation Goals & $2.14^{* * *}$ \\
IV: Constant & $.44^{* * *}$ \\
IV: Multi-Level Strategy Processes & .21 \\
$\mathrm{R}^{2}$ & $88.52^{* * *}$ \\
$\mathrm{~F}$ & \\
\hline Model 2: & $2.33^{* * *}$ \\
DV: Quality Strategic Goal & $.46^{* * *}$ \\
IV: Constant & .19 \\
IV: Multi-Level Strategy Processes & $80.06^{* * *}$ \\
$\mathrm{R}^{2}$ & \\
$\mathrm{~F}$ & \\
\hline Model 3: & $1.96^{* * *}$ \\
DV: Innovation Strategic Goal & $.42^{* * *}$ \\
IV: Constant & .11 \\
IV: Multi-Level Strategy Processes & $40.64^{* * *}$ \\
$\mathrm{R}^{2}$ & \\
$\mathrm{~F}$ &
\end{tabular}


Hypothesis $1 \mathrm{~b}$ states that the achievement of strategic goals mediate the relationship of multi-level strategy processes and financial performance. To investigate this relationship we employed the test for mediation developed by Feedman and Schatzkin (1992)'. This test is consistent with the recommendation for the investigation of a mediating relationship in strategy research outlined by Venkatraman, (1989). That is, mediation specifies the existence of a significant intervening mechanism between an antecedent variable and the consequent variable and is carried out within a path-analytic framework. Moreover, the mediator variable should account for a significant proportion of the relationship between the predictor and the criterion (Venkatraman, 1989, p. 429).

We test Hypothesis $1 \mathrm{~b}$ with a series of regression models (See Table 3), contrasting three strategic goal mediators with the unadjusted regression (multilevel strategic processes on financial performance). First, we tested whether the combined strategic goals of quality and innovation mediated the relationship between multi-level strategic processes and performance (Model $1 \mathrm{v}$. Model 2). Subsequently, we test for the mediating effect of the quality strategic goal (Model $1 \mathrm{v}$. Model 3) and then the innovation strategic goal (Model $1 \mathrm{v}$. Model 4). The results indicate a significant mediating relationship for the combined strategic goal $(t=-5.12, p<.001)$, as well as a significant mediating relationship for the quality goal $(t=-3.20, p<0.001)$ and the innovation goal $(t=-4.67, p<.001)$. This represents a complete mediation model, rather than partial mediation model, because the relationship between multi-level strategic processes and firm performance is not significant without the inclusion of strategic goals (Venkatraman, 1989). We find positive support for Hypothesis $1 \mathrm{~b}$ with all three models, indicating support that strategic goals mediate the relationship between multi-level strategy processes and firm performance.

Hypothesis 2 states that the relationship between multi-level processes and firm performance is stronger when the strategic goal is quality rather than when the strategic goal is innovation. Hypothesis 2 is tested using path analysis, a recommended statistical tool when examining theorized pathways (Asher, 1983). Path analysis uses the unstandardized beta coefficients from the regression equations in Table 4. Hypothesis 2 would be supported if the indirect effects using quality (Indirect Path Model A) are greater than those focusing on innovation (Indirect Path Model B). Hypothesis 2 was not supported as the indirect pathways of quality $\left(.46^{*} .31=.14\right)$ are less than the indirect effect pathways of innovation $(.42 * .35=.15)$. Moreover, the quality pathway accounts for $49 \%$ of the indirect effect and the innovation pathway accounts for $51 \%$ of the effect (Trevino \& Youngblood, 1990$)^{2}$, further evidence that our hypothesis is not supported.

We test Hypotheses $3 a$ and $3 b$ by comparing the regressions of multi-level strategy processes on the strategic goals of quality (Hypothesis 3a) and innovation (Hypothesis $3 b$ ) under conditions of high dynamism and low dynamism. Hypothesis 3 a states that the strength of the relationship between multi-level strategic processes and the strategic goal of quality is greater when environmental dynamism is high compared to when environmental dynamism is low. Responses 
Table 3

\section{Regression Model Estimates}

\section{Regression Model Estimates to Test Hypotheses 1b}

Model 1: Unadjusted Regression for MLSP on Financial Performance

IV: Constant

IV: Multi-Level Strategy Processes ( $\left.\tau^{\prime}\right)$

$2.65^{* * *}$

Standard Error for MLSP Parameter Est. $\left(\sigma_{\mathrm{t}}\right)$

.13

$\mathrm{R}^{2}$

$\mathrm{F}$

1.90

Model 2: Adjusted for Combined Quality \& Innovation Goals

IV: Constant

IV: Multi-Level Strategy Processes $\left(\tau_{1}\right)$

IV: Combined Quality \& Innovation Goals

$-.11$

$.53 * * *$

Standard Error for MLSP Parameter Est. $\left(\sigma_{\tau}\right)^{-}$

$$
\begin{aligned}
& \mathrm{R}^{2} \\
& \mathrm{~F}
\end{aligned}
$$

Mediation test (Model I v. Model 2)'

$-5.12 * * *$

Model 3: Adjusted for Quality Strategic Goal

IV: Constant

IV: Multi-Level Strategy Processes $\left(\tau_{2}\right)$

$1.93^{* * *}$

IV: Quality Strategic Goal

$-.02$

$.31 * * *$

Standard Error for MLSP Parameter Est. $\left(\sigma_{22}\right)$

$\mathrm{R}^{2}$

.10

.04 $\mathrm{F}$

$6.10 * * *$

Mediation test (Model 1 v. Model 3)

$-3.20 * * *$

Model 4: Adjusted for Innovation Strategic Goal

IV: Constant

IV: Multi-Level Strategy Processes $\left(\tau_{3}\right)$

$-.02$

IV: Innovation Strategic Goal

Standard Error for MLSP Parameter Est. $\left(\sigma_{t, 3}\right)$

$\mathrm{R}^{2}$

F

Mediation test (Model 1 v. Model 4) I

1 Freedman and Schatzkin test:

$t_{N-2}=$

$$
\tau-\tau^{\prime}
$$

$$
\sqrt{\sigma^{2}+\sigma^{2}{ }^{\prime}-2 \sigma, \sigma_{t} \cdot \sqrt{1-\rho^{2}{ }_{x i}}}
$$

Where $\rho_{x t}=$ correlation between the independent and intervening variable 
Table 4

Regression Model Estimates

\begin{tabular}{|c|c|}
\hline \multicolumn{2}{|c|}{ Regression Model Estimates to Test Hypotheses 2} \\
\hline Regression Model For Paths & Estimates \\
\hline $\begin{array}{l}\text { Model 1: (Direct Effect) } \\
\text { DV: Financial Performance } \\
\text { IV: Constant } \\
\text { IV: Multi-Level Strategy Processes } \\
\text { R }^{2} \\
F\end{array}$ & $\begin{array}{l}2.65^{* * *} \\
.13 \\
.01 \\
1.90\end{array}$ \\
\hline $\begin{array}{l}\text { Indirect Path Model A: MLSP } \rightarrow \text { Quality } \\
\text { Model Al: } \\
\text { DV: Quality Strategic Goal } \\
\text { IV: Constant } \\
\text { IV: Multi-Level Strategy Processes } \\
\text { R }^{2} \\
\text { F }\end{array}$ & $\begin{array}{c}2.33^{* * *} \\
.46^{* * *} \\
.19 \\
80.06^{* * *}\end{array}$ \\
\hline $\begin{array}{l}\text { Model A2: } \\
\text { DV: Financial Performance } \\
\text { IV: Constant } \\
\text { IV: Multi-Level Strategy Processes } \\
\text { IV: Quality Strategic Goal } \\
\text { R }^{2} \\
\text { F }\end{array}$ & $\begin{array}{l}1.52 * * * \\
-.02 \\
.31 * * * \\
.04 \\
6.10^{* * *}\end{array}$ \\
\hline $\begin{array}{l}\text { Indirect Path Model B: MLSP } \rightarrow \text { Innova } \\
\text { Model B1: } \\
\text { DV: Innovation Strategic Goal } \\
\text { IV: Constant } \\
\text { IV: Multi-Level Strategy Processes } \\
\qquad \text { R }^{2} \\
\text { F }\end{array}$ & $\begin{array}{c}1.96^{* * *} \\
.42 * * * \\
.11 \\
40.64 * * *\end{array}$ \\
\hline $\begin{array}{l}\text { Model B2: } \\
\text { DV: Financial Performance } \\
\text { IV: Constant } \\
\text { IV: Multi-Level Strategy Processes } \\
\text { IV: Innovation Strategic Goal } \\
\mathrm{R}^{2} \\
\mathrm{~F}\end{array}$ & $\begin{array}{c}1.98^{* * *} \\
-.02 \\
.35^{* * *} \\
.07 \\
12.02^{* * *}\end{array}$ \\
\hline
\end{tabular}

One-tailed test: ${ }^{*} \mathrm{p}<.05,{ }^{* *} \mathrm{p}<.01,{ }^{* * *} \mathrm{p}<.001$ 
below the median of the environmental dynamism variable are considered to be facing conditions of low dynamism, while those above the median are considered to be facing conditions of high dynamism. A subgroup analysis is appropriate with testing a moderating relationship (Venkatraman, 1989). To test the sensitivity of our results, we also analyzed the relationships defining high and low dynamism as those being in the top third as well as the top quartile of responses. While the results using the fine grained definitions of dynamism were more significant, we conservatively report the results using the median as the cutoff.

We employed a Chow Test (Chow, 1960) to test the difference in variance explained between high and low dynamism (See Table 5) for the strategic goal of quality. We found that the difference was significant $(\mathrm{F}=3.29, \mathrm{p}=.05)$, and in the direction predicted. Thus, Hypothesis 3 a was supported.

Hypothesis $3 \mathrm{~b}$ states that the strength of the relationship between multi-level strategic processes and the strategic goal of innovation is greater when environmental dynamism is low compared to when environmental dynamism is high. The Chow Test for the strategic goal of innovation indicated that the difference was in the predicted direction and statistically significant $(\mathrm{F}=5.78, \mathrm{p}<.001)$, giving support to Hypothesis $3 \mathrm{~b}$.

Table 5

Regression Model Estimates to Test Hypotheses 3a and 3b

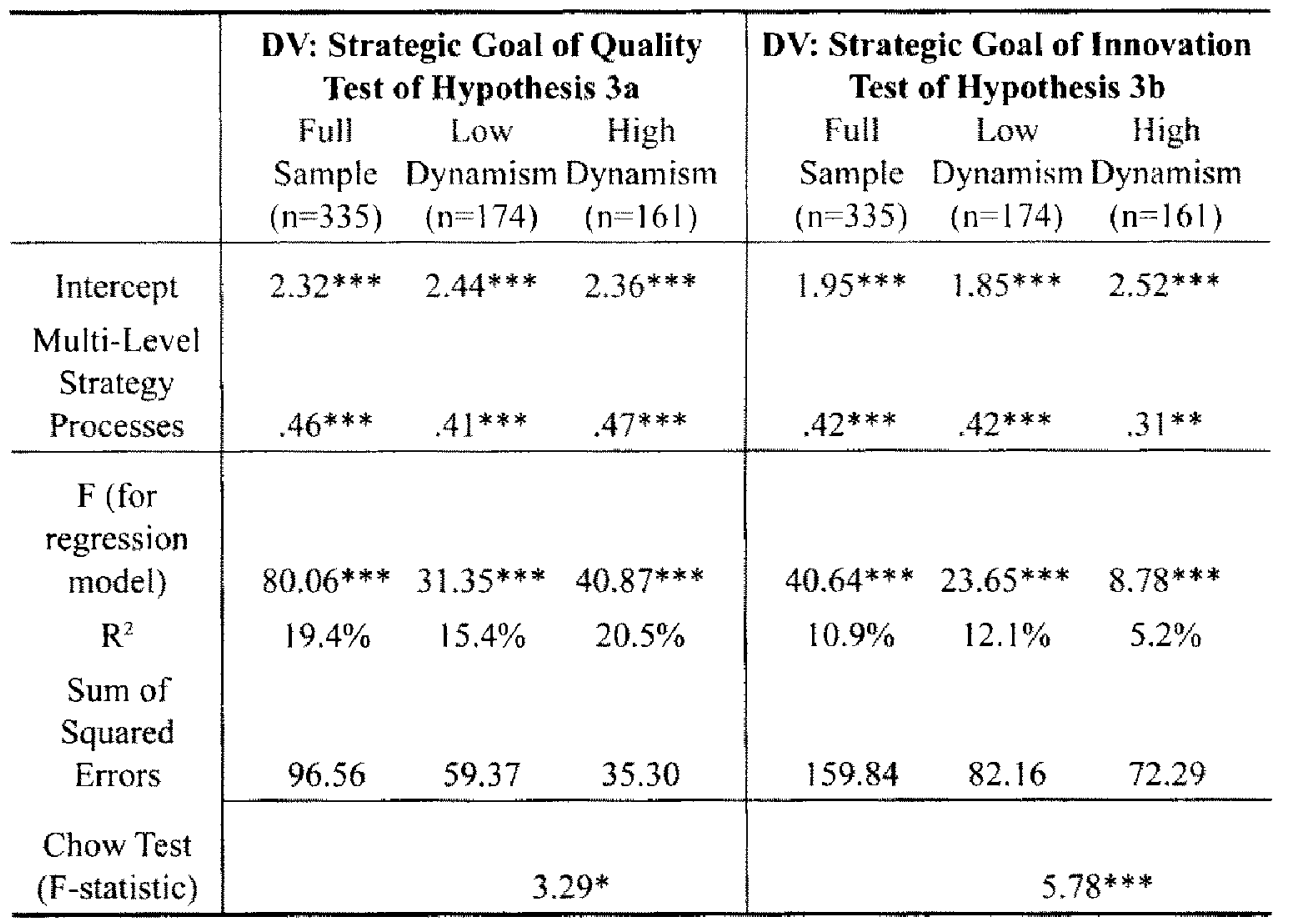

One-tailed test: ${ }^{*} \mathrm{p}<.05,{ }^{* *} \mathrm{p}<.01,{ }^{* * *} \mathrm{p}<.001$ 


\section{Discussion}

Our intent with this investigation is to unravel the complex relationship between multi-level strategy processes, strategic goals and firm performance. We find that there is not a significant relationship between multi-level strategymaking processes and firm performance when strategic goals are not included in the investigation. However, when strategic goals are included as a mediator, a significant relationship is found. If this study had only investigated the direct link, the relationship between multi-level strategy processes and performance would have been missed. This study reveals that the nature of the relationship between multi-level strategy process and financial performance is complex, and that this complexity needs to be incorporated in understanding the relationship between strategy process and firm performance. These results help underscore that indeed there may be a relationship between strategy processes and firm performance that has been here-to-fore underrepresented because of the complex sets of relationships needed to be considered (Rajagopalan et al.,1993).

While the importance of strategic goals has been discussed in strategic management, the insights from research of the organizational behavior scholars of goal formation have not been fully represented in the strategy field. Our results provide evidence of a tie between engaging employees in the goal setting process and achieving the goals. Perhaps more importantly, we provide evidence that the engagement of employees in strategy processes can be related to financial performance. The tie between basic management principles and firm performance has been hypothesized, but the empirical evidence has not been forthcoming. We provide a basis from which this important relationship can be further investigated.

Our findings support the prediction that environmental dynamism moderates the relationship between the engagement of employees and the type of goal being achieved. Our rationale was that quality goals require more communication and coordination and innovation goals involve more competition among subgroups. Therefore, we predicted differences in the strengths of the relationships depending on environmental dynamism. More specifically, our results supported our prediction that the positive relationship between engaging employees in goals of quality and achieving the goals is greater under conditions of higher environmental dynamism. Thus, the payoff for the communication and coordination that is involved in quality goals is greater in more dynamic environments. Moreover, while it is important to engage employees in goals focusing on quality, it is particularly effective in highly dynamic environments. It seems that the communication and coordination necessary for quality goals is particularly beneficial in more dynamic environments.

Consistent with our predictions, we found that involving employees is more effective in achieving the goal of innovation under conditions of low dynamism than under conditions of high dynamism. Our rationale was that there is more competition for ideas among subgroups in innovative goals and less dynamic environments would result in more effective implementation of the strategy 
engagement process. Implementing innovative goals at the organizational level takes longer than at the subgroup level. Time is a luxury more available to firms operating in less dynamic environments. Thus, while there is a positive effect in engaging employees toward innovative goals, it is more effective in less dynamic environments. Moreover, it seems that the high speed that decisions need to be made in highly dynamic environments (Bourgeois \& Eisenhardt, 1988), means that the investment in innovative goals at the organizational level is not as valuable as in less dynamic environments, but valuable nevertheless.

The findings in this investigation help lay the foundation for future studies that link other types of strategy processes and performance. The mediating nature of strategic goals should be investigated with processes such as formal strategic planning. It has been argued that key insights regarding the conflicting evidence regarding the link between strategic planning and firm performance are to come from investigating the impact of mediating variables (Boyd, 1991). We suggest that the mediating role of strategic goals be added to strategy process- performance studies. Future investigations should also explore how firms can grow and yet continue to involve employees at multiple levels of the process strategy making processes. While it is relatively simple to engage the majority of employees in major decisions for small entrepreneurial organizations, it is certainly more difficult as the company grows and matures. Our investigation did not explore whether engaging employees in strategy processes results in better goals being formulated, which could lead to higher financial performance. Future investigations could also unravel this explanation to our findings.

Certain caveats to our findings should be noted. Our methodology used crosssectional survey data, and thus we can only investigate associations, not causality. The problem of reciprocal causality between strategy processes, strategic goals and firm performance is a limitation of other studies and is a limitation of ours as well. Longitudinal investigations are needed to provide greater insight into the relationships that we are presenting. We suggest exploring the relationships between the engaging employees in strategy making processes to more populations to further the generalizability of our results.

Implications of our study to managers suggest that strategy formulation should be made on an iterative basis, involving managers and employees in ongoing dialogue. This is in direct contrast with the traditional models of strategy formulation in which a vision is generated by the leader and then communicated throughout the organization. Involving organization participants in important strategic decisions leads to not only a greater commitment toward the strategic goals but better implementation of these goals. These intangible organizational processes are hard to imitate and can be a source of sustained competitive advantage. This means the political activities involved in strategic processes can be worth the time they entail and will have a payoff in the long run. Managers should also take note that the level of environmental dynamism relates to the strength of the relationship between the engagement of employees and strategic goals. In highly dynamic environments, there will be a higher payoff for engaging employees in 
decisions surrounding quality goals and in less dynamic environments, there will be a higher payoff for engaging employees in decisions surrounding innovative goals. However, our results suggest that whatever strategy a firms is pursuing, the benefits of engaging employees in the process can result in increased financial performance, whatever the environment. This is certain to get the attention of even leaders that run out of patience with the time and resources involved in strategic processes. Our findings underscore the importance of how one travels on the road in business is as important as where the road leads.

\section{References}

Anthony, W, P. (1978), Participative management. Reading, MA: Addison-Wesley.

Asher, H. B. (1983). Causal modeling (2 ${ }^{\text {nd }} e d$.). Beverly Hills, CA: Sage Publications.

Blake, R. R., \& Mouton, J. S. (1970). The managerial grid. Houston: Gulf.

Bourgeois, L. J., \& Eisenhardt, K. M. (1988). Strategic decision processes in high velocity environments: Four cases in the microcomputer industry. Management Science, $34,816-835$.

Bowen, D. E., \& Lawler, E. E. (1992). The empowerment of service workers; What, why, how, and when. Sloan Management Review. 33, 31-39.

Bowles, J. (1992, April). Is American management really committed to quality? Management Review. 81, 42-46

Boyd, B. K. (1991). Strategic planning and financial performance: A meta-analytic review. Journal of Monagement Studies, 28, 354-374.

Brews, P. J., \& Hunt, M. R. (1999). Learning to plan and planning to learn: Resolving the planning school/learning school debate. Strategic Management Journal, 20, 889-913.

Brown, S. L., \& Eisenhardt, K. M. (1998). Competing on the edge: Strategy as structured chaos. Boston: Harvard Business School Press.

Burgelman, R.A. (1983). Managing the internal corporate venturing process: Some recommendations for practice. Administrative Science Quarterly, 28, 223-244.

Burgelman, R.A. (1991). Intraorganizational ecology of strategy making and organizational adaptation: Theory and field research. Organization Science, 2, 239-262.

Chakravarthy, B. S., \& Doz, Y. (1992). Strategy process research: Focusing on corporate self-renewal. Strategic Management Journal, 13, 5-14. 
Chow, G. C. (1960). Tests of equality between sets of coefficients in two linear regressions. Econometrica, 28, 591-605.

Conger, J. A., \& Kanungo, R. N. (1988). The empowerment process: Integrating theory and practice. Academy of Management Review, 13, 471-482.

Cotton, J. L., Vollrath, D. A., Legnick-Hall, M. L., \& Froggatt, K. L. (1990). Fact- the form of participation does matter: A rebuttal to Leana, Lock, and Schweiger. Academy of Management Review, 15, 147-153.

Damanpour, F. (1991). Organizational innovation: A meta-analysis of effects of determinants of moderators. Academy of Management Joumal, 34, 555-590.

Dean, Jr., J. W., \& Bowen, D. E. (1994). Management theory and total quality: Improving research and practice through theory development. Academy of Mamagement Review, 19,392-418.

Eylon, D., \& Au, K. Y. (1996). Exploring empowerment cross-culture differences along the power distance dimensions. Paper presented at the National Academy of Management meeting, Cincinnati, $\mathrm{OH}$.

Floyd, S. W., \& Wooldridge, B. (2000). Building strategy from the middle. Reconceptualizing strategy making process. Beverly Hills, CA: Sage Publications.

Forrester, R. (2000). Empowerment: Rejuvenating a potent idea. The Academy of Management Executive, 14, 67-80.

Freedman, L. S., \& Schatzkin, A. (1992). Sample size for studying intermediate endpoints within intervention trials of observational studies. American Journal of Epidemiology, $136,1148-1159$.

Frost, C. H., Wakely, J. H. \& Ruh, R. A. (1974). The Scanlon Plan for organization development: Identify, participation, and equity. East Lansing: Michigan State University Press.

Fulford, M. D. \& Enz, C. A. (1995). The impact of empowerment on service employees. Joumal of Managerial Issues, $7,161-175$.

Gabor, A. (1990). The man who discovered quality: How W. Edwards Deming brought the quality revolution to America-The stories of Ford, Xerox, \& GM. New York: Random House.

Goll, R., \& Rasheed, A. M. A. (1997). Rational decision-making and firm performance: The moderating role of environment. Strategic Management Journal, 18, 583-591.

Hamel, G., \& Prahalad, C. K. (1994). Competing for the future. Boston: Harvard Business School Press. 
Hart, S. (1992). An integrative framework for strategy-making processes. Academy of Management Review, 17, 327-351.

Hart, S., \& Banbury, C. (1994). How strategy-making processes can make a difference. Strategic Management Journal, 15, 251-269.

Huff, A., \& Reger, R. (1987). A review of strategic process. Journal of Management. $13(2), 211-236$.

Jelinek, M., \& Schoonhoven, C. B. (1990). The innovation marathon. Oxford, U.K.: Basil Blackwell.

Kantor, R. M. (1988). When a thousand flowers bloom: Structural, collective, and social conditions for innovation in organization. Research in Organizational Behavior, 10, 169-211.

Kantor, R. M. (1989). The new managerial work. Harvard Business Review, 66, 85-92.

Kaplan, R., \& Norton, D. (1996, January-February). Using the balanced scorecard as a strategic management system. Harvard Business Review, 74, 75-85.

Koberg, C. S., Boss, R. W., Senjem, J. C., \& Goodman, E. A. (1999). Antecedents and outcomes of empowerment: Empirical evidence from the health care industry. Group and Organization Management, 24, 71-91.

Kuratko, D. F., Hornsby, J. S., \& Corso, L. M. (1996, Spring). Building an adaptive firm. Small Business Forum, 14, 41-48.

Lawler, E. E. (1986). High involvement management. San Francisco: Jossey-Bass.

Lawler, E. E. (1992). The ultimate advantage. San Francisco: Jossey-Bass.

Lawler, E. E., Mohrman, S. A., \& Ledford, G. (1992). Employee involvement and total quality management: Practices and results in Fortune 1,000 companies. San Francisco: Jossey-Bass.

Lawler, E. E., Mohrman, S. A., \& Ledford, G. (1995). Creating high performance organizations. San Francisco: Jossey-Bass.

Lawrence, P., \& Lorsch, J. (1967). Organization and environment. Boston: Harvard Business School Press.

Ledford, G. E., Jr., \& Lawler, E. E., III. (1994). Dialogue: Research on employee participation: Beating a dead horse? Academy of Management Review, 19 (4), 633-636.

Likert, R. (1961). New patterns of management. New York: McGraw-Hill. 
Locke, E. A., Latham, G. P., \& Erez, M. (1988). The determinants of goal commitment. The Academy of Management Review, 13(1). 23-39.

MacKinnon, D. P., Lockwood, C. M., Hoffman, J. M., West, S. G., \& Sheets, V. (2002). A comparison of methods to test mediation and other intervening variable effects. Psychological Methods, 7(l), 83-104.

Maier, N. R. F. (1963). Problem solving discussions and conferences: Leadership methods and skills. New York: McGraw-Hill.

McGregor, D. (1960). The human side of enterprise. New York: McGraw-Hill.

Melcher, A. J. (1976). Participation: A critical review on research findings. Human Resource Management, 15, 12-21.

Miller, C. C., \& Cardinal, L. B. (1994). Strategic planning and firm performance: A synthesis of more than two decades of research. Academy of Management Journal, $37,1649-1665$.

Miller, D., \& Friesen, P. H. (1983). Strategy making and environment: The third link. Strategic Management Journal, 4, 221-235.

Miller, D., \& Lee, J. (2001). The people make the process: Commitment to employees, decision making, and performance. Journal of Management, 27, 163-190.

Miller, K. \& Monge, P. R. (1986). Participation, satisfaction, and productivity: A metaanalytic revicw. Academy of Management Journal, 29, 727-753.

Milliken, F. J. (1990). Perceiving and interpreting environmental change: An examination of college administrators' interpretation of changing demographics. Academy of Management Journal, 33, 42-63.

Miron, E., Erez, M., \& Naveh, E. (2004). Do personal characteristics and cultural values that promote innovation, quality, and efficiency compete or complement each other? Journal of Organizational Behavior, 25, 175-199.

Monge, P. R., Cozzens, M. D., \& Contractor, N. S. (1992). Communication and motivational predictors of the dynamics of organizational innovation. Organization Science, 3, 250-274.

Ozer, E. M. \& Bandura, A. (1990). Mechanisms governing empowerment effects: A selfefficacy analysis. Journal of Personality and Social Psychology, 5, 472-486.

Pfeffer, J. (1994). Competitive advantage through people: Unleashing the power of the work force. Boston: Harvard Business School Press.

Port, O., \& Smith, G. (1995, January 14). The straining of quality. The Economist, 55-56. 
Powell, T. C. (1992). Strategic planning as competitive advantage. Strategic Management Journal, 13, 551-558.

Powell, T. C. (1995). Total quality management as competitive advantage: A review and empirical study. Strategic Management Journal, 16, 15-37.

Powell, T. C. (1996). How much does industry matter? An alternative empirical test. Strategic Management Journal. 17, 323-334.

Rajagopalan, N., Rasheed, A. M., \& Datta, D. K. (1993). Strategic decision processes: Critical review and future directions. Journal of Management, 19, 349-384.

Ritchie, J. B., \& Miles, R. E. (1970). An analysis of quantity and quality of participation as mediating variables in the participative decision making process. Personnel Psychology. 23, 347-359.

Robins, J. A. (2004). When does the age of data matter? Notes on the selection of data for strategy research. In D.J. Ketchen \& D.D. Bergh (Eds.), Research Methodology in Strategy and Management, Volume 1, 251-271.

Rudolph H. R., \& Peluchette, J. V. (1993). The power gap: Is sharing or accumulating power the answer? Journal of Applied Business Research, 9, 12-20.

Salancik, G. R. (1977). Commitment and the control of organizational behavior and belief. In B.M. Staw \& G. Salancik (Eds.), New Directions in Organizational Behavior (154). Chicago: St. Clair.

Spreitzer, G. M. (1995). Psychological empowerment in the workplace: Dimensions, measurement, and validation. Academy of Management Journal, 38, 1442-1465.

Spreitzer, G. M. (1996). Social structural characteristics of psychological empowerment. Academy of Management Journal, 39, 483-504.

Tegarden, L. F., Sarason, Y., \& Banbury, C. (2003). Linking strategy processes to performance outcomes in dynamic environments: The need to target multiple bull's eyes. Journal of Managerial Issues, 15, 133-153.

Trevino, L. K., \& Youngblood, S. A. (1990). Bad apples in bad barrels: A causal analysis of ethical decision-making behavior. Journal of Applied Psychology, 75, 378-385.

Van de Ven, A., \& Ferry, D. (1979). Measuring and assessing organizations. New York: The Free Press.

Venkatraman, N. (1989). The concept of fit in strategy research: Toward verbal and statistical correspondence. Academy of Management Review, 14 (3), 423-444.

Von Hippel, E. (1988). The sources of innovation. New York: Oxford University Press. 
Wagner, J.A., III. (1994). Participation"s effects on performance and satisfaction: A reconsideration of the research evidence. Academy of Management Review, 19, 312-330.

Willard, G. E., Krueger, D. A., \& Fesser, H. R. (1992). In order to grow, must the founder go: A comparison of performance between founder and non-founder managed highgrowth manufacturing firms. Journal of Business Venturing. 7. 181-194.

Wooldridge, B., \& Floyd, S. W. (1990). The strategy process, middle management involvement and organizational performance. Strategic Management Journal, 11, 231-241.

Zimmerman, M. A. (1990). Taking aim on empowerment research: On the distinction between individual and psychological conceptions. American Journal of Community Psychology. 18, 169-177.

\section{Footnotes}

${ }^{1}$ The merits of this test are discussed by MacKinnon, Lockwood, Hoffman, West and Sheets (2002).

${ }^{2}$ This contrast is calculated by dividing the path indirect effect by the total indirect effects.

Linda F. Tegarden (Ph.D., University of Colorado at Boulder) is an Associate Professor of Strategic Management. Her research interests include the role of networks and geographic clusters in technology-driven environments, strategy process and strategic planning effectiveness in high velocity environments, the use and effectiveness of cognitive mapping in strategic planning processes.

Yolanda Sarason (Ph.D., University of Colorado at Boulder) is an Assistant Professor of Strategic Management and Entrepreneurship at Colorado State University. Her research interests include organizational identity and structuration theory, strategy process in high technology and high velocity environments, and the role of cognition in the strategic management and entrepreneurship areas.

J. Stephen Childers (ABD, Virginia Tech) is an Assistant Professor of Management at Radford University. His research interests build upon the Schumpeterian view of innovation; where change is recognized, organized, and achieved by entrepreneurial insight within organizations. Mr. Childers' interests in strategy and change were formed during his experiences working, managing, and consulting with firms both domestically and internationally.

Donald E. Hatfield (Ph.D., University of California at Los Angeles) is an Associate Professor of Strategic Management at Virginia Tech. His current interests deal with the interaction between the fields of economics, finance, organizational 
theory, and strategic management. Dr. Hatfield's current research is focused upon how managers can deal with the uncertainty associated with technology, and the underlying factors driving geographic industrial clustering. 
